\title{
Surface Characterization of 309 and 310 Steel after the Corrosion in Wood Biomass Ash
}

\author{
A. Dębowska*, A. Kopia, I. Kalemba-Rec, P. Petrzak and A. Magdziarz \\ Faculty of Metals Engineering and Industrial Computer Science, AGH University of Science and Technology, \\ Al. A. Mickiewicza 30, 30-059 Krakow, Poland
}

\begin{abstract}
The aim of this study was to investigate the influence of biomass ashes - specifically wood biomass ash on the surface of austenitic stainless steel 309 and 310 . The process was carried out for $1000 \mathrm{~h}$ at $650{ }^{\circ} \mathrm{C}$. The microstructure and chemical composition of corrosion products were examined by scanning electron microscopy with energy dispersive spectroscopy analysis. Phase analysis of corrosion product were done by X-ray diffraction and ash composition was investigated by X-ray fluorescence. It was observed that wood biomass ash caused the corrosion of the steel surface. On the surface of the steels exposed to wood biomass ash the layer of corrosion products was observed, mostly chromium, nickel and iron oxide. The thickness of mill scale formed during the process was in the range of $h=15-30 \mu \mathrm{m}$.
\end{abstract}

DOI: 10.12693/APhysPolA.131.1387

PACS/topics: 61.66.Dk, 61.05.cp, 68.37.Hk, 88.20.dd

\section{Introduction}

Recently, fossil fuels have been widely used for energy production [1-3]. However, there is a need to replace these energy sources to more environmental friendly energy generators such as biomass. The replacement of fossil fuels by renewable fuels provides to environmental advantages such as reduction of greenhouse gases emission, as well as economic benefits.

The use of biomass in combustion process has increased. Currently, about $75 \%$ of "green energy" is obtained from the combustion of biomass and biofuels $[4,5]$. The process of co-firing of coal and biomass is also commonly used [6-10].

The term "biomass" is understood as a material derived from living organisms or organic matter. Biomass can be converted to commercial products $[11,12]$. Thermochemical (combustion, pyrolysis or gasification process) and biological conversion processes can be applied. Traditionally, biomass combustion process allows to obtain heat supply and power in the industry. For energy generation, biomass is commonly delivered from plants (from energy crops), agricultural products, organic waste, wood, and wood processing waste $[13,14]$. The ash formed after the combustion of biomass contains calcium, magnesium, silicon, and alkali metals $[1,2]$.

Combustion of biomass is applied with proper efficiency, but the ash deposit is a problem which occurs during the process [15-18]. On the heating surface of the boiler the ash deposit can be formed. It may cause phenomena such as slagging, bed agglomeration, fouling and corrosion in combustion devices, thus the risk of quicker equipment damage appears. The process of ash deposit

*corresponding author; e-mail: debovska@agh.edu.pl formation depends on the chemical composition of the fuel and combustion parameters such as temperature or atmosphere.

Corrosion process can be considered as a destruction of materials under the influence of the environment. The power boiler corrosion can appear under the influence of combustion products on a metallic material surface [1921]. Corrosion of structural elements is therefore one of the most common problems that takes place during combustion and co-combustion of biomass. In order to prevent the corrosion of structural elements, certain compact solutions (to increase the efficiency of the process) are applied such as protective coating on the surfaces of the material.

The three most important classes of materials used for operation under the ultra supercritical (increased temperature and pressure) condition, when the risk of corrosion occurrence is high, are: austenitic steels, ferritic steels, and nickel-based superalloys.

In the presented work the characterization of two types of weld overlay (cold metal transfer technique, CMT) austenitic stainless steels (309 and 310) under the corrosion condition, caused by biomass ash from wood biomass, was investigated.

\section{Methodology}

For this study one type of biomass ash was used. Sample was produced in existing energy unit. The biomass for combustion was the typical Polish wood waste (various kinds of wood). The chemical composition of biomass ash was determined by an X-ray fluorescence spectrometer (XRF) (Bruker S8 TIGER XRF spectrometer).

The corrosion process was investigated using samples of steel type 309 and 310 . The samples were cutting from boiler tube with cladding coating (of steel type 309 and 310 ) by CMT on steel $16 \mathrm{Mo} 3$. The grades of presented steels are commonly used for high temperature applica- 
tions. The chemical composition of 309 and 310 steel, analysis using EDS, is presented in Table I.

TABLE I

The chemical composition of steel 309 and 310

\begin{tabular}{c|c|c|c|c|c|c|c|c}
\hline \hline \multirow{2}{*}{ Steel } & \multicolumn{10}{c}{ Element content [wt\%] } \\
\cline { 2 - 9 } & $\mathrm{C}$ & $\mathrm{Si}$ & $\mathrm{Mn}$ & $\mathrm{Cr}$ & $\mathrm{Ni}$ & $\mathrm{P}$ & $\mathrm{S}$ & $\mathrm{Fe}$ \\
\hline 309 & $\leq 022$ & 0.9 & 2.5 & 24 & 13 & $\leq 0.045$ & $\leq 0.015$ & bal. \\
310 & $\leq 022$ & 0.5 & 1.9 & 27 & 20 & $\leq 0.045$ & $\leq 0.015$ & bal.
\end{tabular}

The corrosion products formation in high temperature conditions was investigated. Weld overlays of steel 309 and 310 samples were covered by wood biomass ash and placed into furnace for $1000 \mathrm{~h}$ at $650^{\circ} \mathrm{C}$. After the process the surface and cross-section of steel were examined using scanning electron microscopy (SEM) method.

The phase analysis of the corrosion product, which occurred on the surface of steels, was investigated by X-ray diffraction (XRD) using PANanalytical EMPYERAN DY 1061 with $\mathrm{Cu} K_{\alpha}$ radiation in the BraggBrentano geometry (angle range $2 \theta=20-90^{\circ}$, copper $\operatorname{lamp} \lambda=1.54 \AA$ ).

A scanning electron microscopy with energy dispersive spectrometry (SEM-EDX) was applied to performed analysis of surface and cross-section of steel samples after the corrosion process. The FEI Quanta 3D FEG Dual Beam microscope was used. SEM-EDX study was also conducted to obtain information about main elements distribution in the layer which was formed during the process. The samples were observed by secondary electrons using the acceleration voltage -2 and $10 \mathrm{kV}$ (surface analysis) or $20 \mathrm{kV}$ (EDS maps of elements).

\section{Results and discussion}

The chemical composition of biomass ash is presented in Table II. Major inorganic elements in the investigated ash is given in form of oxide.

TABLE II

The chemical composition of ash from wood biomass determined by XRF method [22]

\begin{tabular}{c|c|c|c|c|c|c|c|c|c|c}
\hline \hline \multicolumn{1}{c}{ Chemical composition [wt\%] } \\
\hline $\mathrm{SiO}_{2}$ & $\mathrm{Al}_{2} \mathrm{O}_{3}$ & $\mathrm{Fe}_{2} \mathrm{O}_{3}$ & $\mathrm{TiO}_{2}$ & $\mathrm{CaO}$ & $\mathrm{MgO}$ & $\mathrm{K}_{2} \mathrm{O}$ & $\mathrm{Na}_{2} \mathrm{O}$ & $\mathrm{MnO}$ & $\mathrm{P}_{2} \mathrm{O}_{5}$ & $\mathrm{SO}_{3}$ \\
\hline 9.80 & 2.51 & 1.34 & 0.08 & 45.90 & 10.70 & 13.00 & 0.71 & 3.18 & 10.00 & 2.79
\end{tabular}

The XRF results shows that wood biomass ash used in this study is mainly composed of calcium $(\% \mathrm{CaO}$ $=45.90$ ) but there is also significant amount of $\mathrm{MgO}$, $\mathrm{K}_{2} \mathrm{O}$ and $\mathrm{P}_{2} \mathrm{O}_{5}$. According to the literature [23] the main elements which accelerate the process of corrosion are $\mathrm{Na}$, $\mathrm{K}, \mathrm{S}$, and $\mathrm{Cl}$, thus such a high content of $\mathrm{K}_{2} \mathrm{O}$ suggested aggressive character of investigated biomass ash. Figure 1 presents SEM images of steel 309 (a) and 310 (b) after the corrosion process with XRD results.

On the surface of investigated steels, corrosion products were observed. According to the type of steels which was used, different kinds of phases were identified. For both steels the main products of corrosion were chromium and iron oxides. The presence of compounds such as $\mathrm{K}_{2} \mathrm{CrO}_{4}$ and $\mathrm{CaCO}_{3}$ is a result of steel elements reaction with ashes while heating process. In case of steel 309 such phases can be distinguished: $\mathrm{Fe}_{3} \mathrm{O}_{4}$, $\mathrm{Fe}_{2} \mathrm{O}_{3}, \mathrm{NiO}, \mathrm{CaCO}_{3}, \mathrm{~K}_{2} \mathrm{CrO}_{4}$, while on the surface of steel 310 phases such as $\mathrm{Fe}_{3} \mathrm{O}_{4}, \mathrm{Fe}_{2} \mathrm{O}_{3}, \mathrm{~K}_{2} \mathrm{CrO}_{4}, \mathrm{Cr}_{2} \mathrm{O}_{3}$ occurred. Cross-section of metal samples after the exposure to wood biomass ash are presented in Fig. 2.
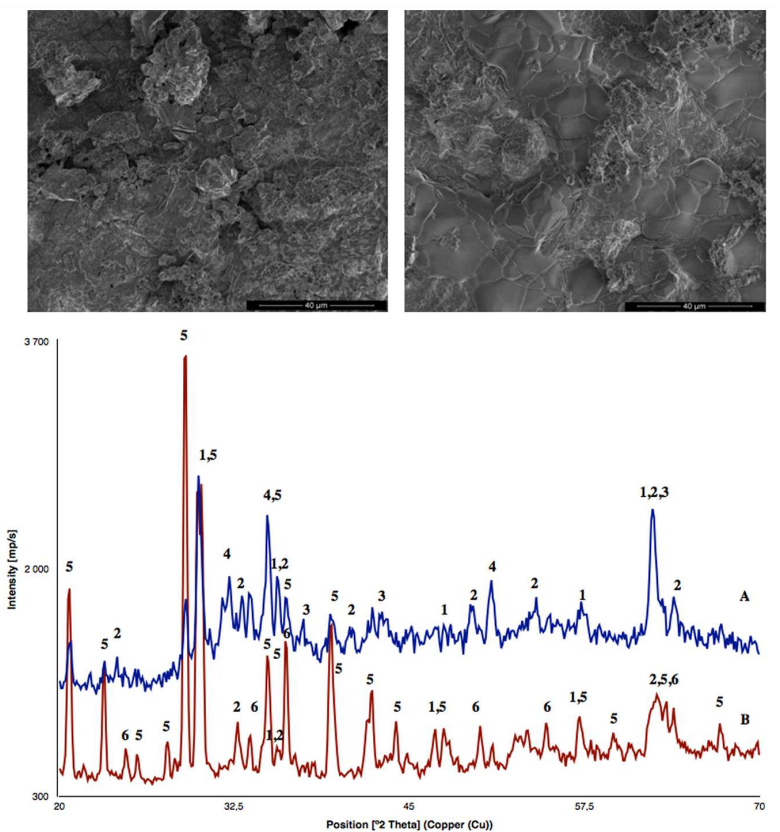

Fig. 1. SEM images of steel 309 (A) and 310 (B) after the exposure to wood biomass ash and XRD patterns of corrosion products, $1-\mathrm{Fe}_{3} \mathrm{O}_{4}, 2-\mathrm{Fe}_{2} \mathrm{O}_{3}, 3-\mathrm{NiO}$, $4-\mathrm{CaCO}_{3}, 5-\mathrm{K}_{2} \mathrm{CrO}_{4}, 6-\mathrm{Cr}_{2} \mathrm{O}_{3}$.

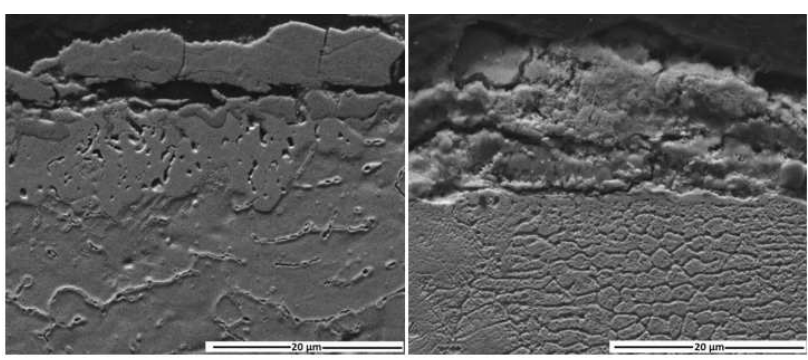

Fig. 2. SEM images of steel 309 (A) and 310 (B) crosssection after the exposure to wood biomass ash.

The structure of layer formed during the corrosion process is divided into two parts (Fig. 2a, layer I and II). The thickness of formed oxides coating during the process was in the range of $h=15-30 \mu \mathrm{m}$. In case of both steels, 309 (Fig. 2a) and 310 (Fig. 2b) the formed layer is not compact, with visible cracks. Moreover, layers are not homogeneous. Further, it may be noticed that inside the space between those two divided layers, in some places, corrosion products are located (Fig. 2b).

In order to determine the chemical composition and division of elements in this double layer, the EDS map of 


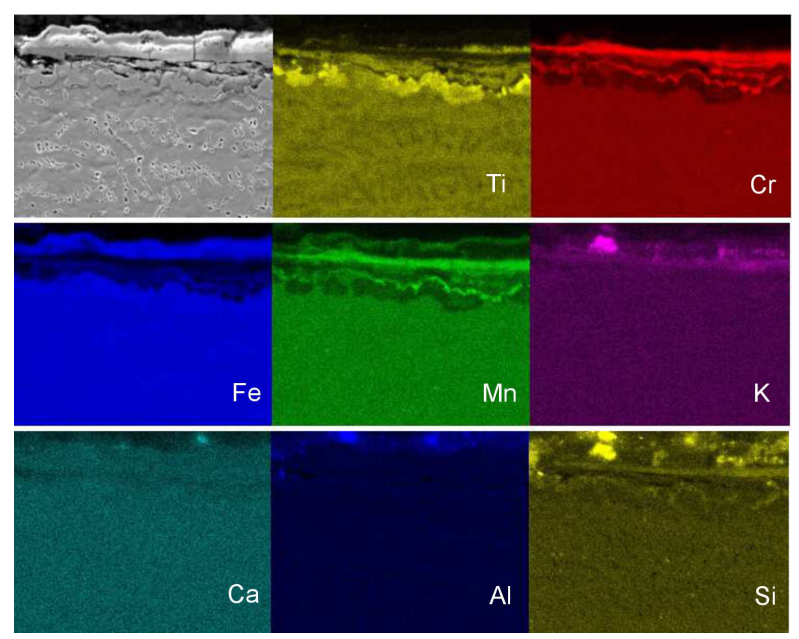

Fig. 3. Map of elements, steel 309 after the corrosion process; heating with ash from wood biomass, $t=1000 \mathrm{~h}, T=650^{\circ} \mathrm{C}$.

elements was done. Results were similar (with no significant changes) for both steel samples, thus in Fig. 3 only analysis for steel 309 was presented.

Figure 3 presents that the lower layer (the steel side) contains mostly nickel, chromium and manganese oxides. The elements from ash such as $\mathrm{K}, \mathrm{Ca}, \mathrm{Al}$, or Si and also iron oxide are located in the upper layer. Diffusion of elements from ash is inhibited to the steel, but we observed strong diffusion of iron to the surface and forming of iron oxide.

\section{Conclusions}

In the present study two austenitic stainless steels 309 and 310 after the exposure to wood biomass ash were investigated. Sample of examined biomass ash was typical ash with high content of $\mathrm{Ca}, \mathrm{K}$, as well as $\mathrm{Na}, \mathrm{Mg}$ and Si.

For steel 309, the formed layer is not compact, with visible cracks, which may allow to continue the corrosion process. The phases identified on the surface were $\mathrm{Fe}_{2} \mathrm{O}_{3}, \mathrm{Fe}_{3} \mathrm{O}_{4}$, and $\mathrm{K}_{2} \mathrm{CrO}_{4}, \mathrm{NiO}, \mathrm{Ca}_{2} \mathrm{CO}_{3}$. The formed layer on steel 310 is also not homogeneous and XRD analysis show phases such as: $\mathrm{K}_{2} \mathrm{CrO}_{4}$, chromium and iron oxides. The SEM and XRD analysis of the steel surface and cross-section after corrosion process showed that for both steels corrosion products occurred after heating with wood biomass ash. Even that steel 310 is composed of higher $\mathrm{Cr}$ and $\mathrm{Ni}$ content, the formed $\mathrm{Cr}$ and $\mathrm{Ni}$ oxide layer in such aggressive environment do not improve corrosion resistance, thus on the surface of both materials iron oxides can be observed.

\section{Acknowledgments}

The research leading to these results has received funding from the Polish-Norwegian Research Programme operated by the National Centre for Research and Development under the Norwegian Financial Mechanism 2009-2014 in the frame of Project Contract No Pol_Nor $/ 208189 / 105 / 2015$.

\section{References}

[1] A. Magdziarz, A.K. Dalai, J.A. Koziński, Fuel 176 , 135 (2016).

[2] A. Magdziarz, M. Wilk, M. Gajek, D. Nowak-Woźny, A. Kopia, I. Kalemba-Rec, J.A. Koziński, Energy 113, 85 (2016).

[3] A.A. Khan, W. de Jong, P.J. Jansens, H. Spliethoff, Fuel Process Technol. 90, 21 (2009).

[4] H. Haberl, T. Beringer, S.C. Bhattacharya, K.H. Erb, M. Hoogwijk, Curr. Opin. Environment. Sustainabil. 2, 394 (2010).

[5] K. Srirangan, L. Akawi, M.Y. Murray, C.P. Chou, Appl. Energy 100, 172 (2012).

[6] S.G. Sahu, N. Chakraborty, P. Sarkar, Renew. Sustainable Energy Rev. 39, 575 (2014).

[7] P. Basu, Biomass Gasification, Pyrolysis and Torrefaction. Practical Design and Theory, 2nd ed., Elsevier, San Diego 2013.

[8] J. Werther, in: 20th Int. Conf. on Fluidized Bed Combustion, Xi'an (China), Eds. Guangxi YueHai, Zhang Changsui, ZhaoZhongyang Luo, 2009, p. 27.

[9] R. Saidur, E.A. Abdelaziz, A. Demirbas, M.S. Hossain, S. Mekhilef, Renew. Sustain. Energy Rev. 15, 2262 (2011).

[10] R.G. Fernandez, C.P. García, A.G. Lavín, J.L.B. de las Heras, Fuel Process. Technol. 103, 16 (2012).

[11] L. Wang, C.L. Weller, D.D. Jones, M.A. Hanna, Biomass Bioenergy 32, 573 (2008).

[12] Y. Lin, S. Tanaka, Appl. Microbiol. Biotechnol. 69 , 627 (2006).

[13] S.V. Vassilev, D. Baxter, L.K. Andersen, C.G. Vassileva, Fuel 89, 913 (2010).

[14] S.V. Vassilev, D. Baxter, L.K. Andersen, C.G. Vassileva, T.J. Morgan, Fuel 94, 1 (2012).

[15] M. Ohmam, A. Nordin, B.J. Skrifvars, R. Backman, M. Hupa, Energy Fuels 14, 169 (2000).

[16] C. Luan, C. You, D. Zhang, Energy 69, 562 (2014).

[17] B.M. Steenari, A. Lundberg, H. Pettersson, M. Wilewska-Bien, D. Andersson, Energy Fuels 23, 5655 (2009).

[18] R.A. Antunes, M.C.L. de Oliveira, Corros. Sci. 76, (2013).

[19] S.A. David, J.A. Siefert, Z. Feng, Sci. Technol. Weld Joining 18, 631 (2013).

[20] J.A. Siefert, S.A. David, Sci. Technol. Weld Joining 19, 271 (2014).

[21] S.A. David, J.A. Siefert, J.N. DuPont, J.P. Shingledecker, Sci. Technol. Weld Joining 20, 532 (2015).

[22] A. Magdziarz, D. Nowak-Woźny, M. Gajek, M. Wilk, in: Renewable Energy, in press (2017).

[23] R. Wasilewski, J. Hrabak, Archiwum Gospodarki Odpadami i Ochrony Środowiska 17, 1 (2015), (in Polish). 